\title{
Host range and whitefly transmission efficiency of Tomato severe rugose virus and Tomato golden vein virus in tomato plants
}

\author{
Mônica A. Macedo ${ }^{1,2} \cdot$ Miguel Michereff Filho ${ }^{1}$. Jesús Navas-Castillo ${ }^{3}$. \\ Alice K. Inoue-Nagata ${ }^{1,2}$
}

Received: 25 April 2015 / Accepted: 22 September 2015 / Published online: 19 October 2015

(C) Sociedade Brasileira de Fitopatologia 2015

\begin{abstract}
Begomoviruses are the most important viruses affecting tomato (Solanum lycopersicum) crops in Brazil. Tomato severe rugose virus (ToSRV) is the most predominant species, followed by Tomato golden vein virus (TGVV). We evaluated the putative effect of host range and whitefly transmission efficiency on the predominance of ToSRV. Whitefly (Bemisia tabaci, B biotype or MEAM 1) vectors carrying the two viruses were allowed to freely inoculate plants of 27 species, maintained in cages. Visual and PCR detection indicated that ToSRV could infect five plant species and TGVV could infect six species. Transmission studies were performed in single or double infections in tomato plants. ToSRV infected a higher percentage of plants than TGVV (single or mixed inoculation) in all trials. The rates of acquisition of ToSRV and TGVV, however, did not differ significantly between insects fed on tomato leaves with single or mixed infections. A higher transmission efficiency of ToSRV by whiteflies under the agricultural conditions of tomato cultivation in Brazil may thus contribute to the predominance of ToSRV in the field.
\end{abstract}

Section Editor: F. Murilo Zerbini

Alice K. Inoue-Nagata

alice.nagata@embrapa.br

1 Embrapa Hortaliças, Brasília, DF 70351-970, Brazil

2 Dep. de Fitopatologia, Universidade de Brasília, Brasília, DF 70910-000, Brazil

3 Instituto de Hortofruticultura Subtropical y Mediterránea "La Mayora", Universidad de Málaga - Consejo Superior de Investigaciones Científicas (IHSM-UMA-CSIC), Algarrobo-Costa, Málaga 29750, Spain
Keywords Begomovirus · Bemisia tabaci · Geminiviridae • Solanum lycopersicum · Tomato golden vein virus · Tomato severe rugose virus · Whitefly

Golden mosaic disease caused by begomoviruses (genus Begomovirus, family Geminiviridae) is a major concern in many crops around the world. Significant losses due to high incidences of begomoviruses have been reported in tomato, bean, cowpea, cotton, and chili crops in the Americas (Faria et al. 2000; Morales and Anderson 2001). Many weed species have also been reported as hosts of begomoviruses in several countries, including Brazil (Morales and Anderson 2001; Barbosa et al. 2009). Begomoviruses are naturally transmitted by the whitefly Bemisia tabaci (Hemiptera: Aleyrodidae) (Rojas et al. 2005; Brown et al. 2012) in a persistent and circulative manner (Hunter et al. 1998; Rosello et al. 1999; Ghanim et al. 2001). Seventeen species of begomoviruses have been reported to infect tomatoes in Brazil (Ribeiro et al. 2003; Fernandes et al. 2006; Calegario et al. 2007; Castillo-Urquiza et al. 2008; Albuquerque et al. 2010). The rapid emergence of begomoviruses in this pathosystem may be due to the high frequency of observed recombination events, therefore resulting in their rapid evolution (Rocha et al 2013). Nevertheless, three species are most commonly found in the field: $T_{0}$ mato severe rugose virus (ToSRV) is the most predominant and is found throughout the country, Tomato golden vein virus (TGVV) in common in the southeastern and midwestern regions, and Tomato mottle leaf curl virus (TMoLCV) is widespread in the northeast (Fernandes et al. 2008). The predominance of a specific virus in a region can be due to several factors, such as vector specificity, host range, viral adaptation to local climatic conditions, and cultivation system. This topic has been poorly studied, especially for bipartite begomoviruses in Brazil. The objective of this study was to compare the host 
ranges and whitefly transmission efficiencies of ToSRV and TGVV isolates and to discuss the possible relationship between these properties and the predominance of ToSRV in the field.

The experiments were performed at the Laboratory of Virology and in the greenhouse of Embrapa Hortaliças in the Federal District of Brazil. The viral sources were prepared by agrobacterium-mediated inoculation of infectious clones of ToSRV (ToSRV-1164) and TGVV (TGVV-1799) in tomato plants (Solanum lycopersicum cv. Viradoro) in an insect-proof greenhouse. The whitefly population used for the transmission tests has been maintained for several generations on cabbage plants (Brassica oleracea var. capitata), a non-host for Brazilian tomato begomoviruses. The whiteflies were identified as the $\mathrm{B}$ biotype of the $B$. tabaci complex [also known as Middle EastAsia Minor 1 (MEAM 1) species]. PCR amplification of part of the mitochondrial cytochrome oxidase I gene of the whitefly population was amplified with primers C1-J-2195-FW (5'-TTG ATT TTT TGG TCA TCC AGA AGT-3') and C1-J-2195-RV (5'-TCC AAT GCA CTA ATC TGC CAT ATT A-3') (Simon et al. 1994; Frohlich et al. 1999), followed by enzymatic digestion of the amplicons with TaqI, according to Bosco et al. (2006).

The host ranges of both viruses were first tested by whitefly inoculation in a free-choice feeding test using 5-19 replications of 27 plant species: Abelmoschus esculentus, Capsicum annuum cv. Tico, C. baccatum cv. Mari, Chenopodium amaranticolor, C. quinoa, Crotalaria incana, C. ochroleuca, Cucurbita pepo cv. Caserta, Datura metel, D. stramonium, Euphorbia heterophylla, Gomphrena globosa, Gossypium hirsutum, Glycine max, Ipomoea aristolochiaefolia, I. setosa, Nicandra physaloides, Nicotiana benthamiana, N. rustica, N. tabacum cv. Samsun and cv. TNN, Phaseolus vulgaris, Physalis pubescens, Senna obtusifolia, Sida rhombifolia, Solanum americanum and $S$. lycopersicum cv. Viradoro (tomato).

The viral sources were tomato plants inoculated with ToSRV or TGVV approximately 30 days before acquisition and showing characteristic symptoms of interveinal chlorosis (begomoviral infection in the source plants was confirmed by PCR as described below). Large populations of whiteflies (approximately 400 insects) were allowed to mass feed on tomato plants infected with ToSRV or TGVV for a 48-h acquisition access period in a $50 \mathrm{ml}$ tube. The whiteflies (two tubes per cage) were then transferred to cages containing the various trial host plants for a 7-day inoculation access period, after which an insecticide (Thiamethoxam) was applied to eliminate the insects. The trial cages contained up to 24 pots with healthy young plants (3-4 true-leaf stage). In each cage, different plant species were added with at least two tomato plants as the susceptible control. Inoculation of ToSRV and TGVV was done at the same time in cages with identical composition of plants.

Total DNA was extracted from the upper leaves of the inoculated plants to confirm successful infection, based on the method developed by Doyle and Doyle (1987), and stored at $-20{ }^{\circ} \mathrm{C}$ until use. The two begomoviruses were detected by
PCR using specific primers for each species: ToSRV1f (5'TCT TTG AAG GCG GCA GAA GG-3') and ToSRV2r (5'CTC ATA GTT AGC GGC CTT TTT-3'), which amplify a fragment of ca. $820 \mathrm{bp}$ from ToSRV DNA-A, and TGVV1f (5'-GCS AAG TTG AGA TTT GAT CT-3') and TGVV 6r (5'TCG GGT CTA GAG CTC ATC-3'), which amplify a fragment of ca. $440 \mathrm{bp}$ from TGVV DNA-A (Fernandes et al. 2010).

PCRs for all assayed plant species, performed 21 days after free-choice whitefly inoculation, identified both viruses only in Nicandra physaloides, Nicotiana rustica, Capsicum baccatum cv. Mari and S. lycopersicum (Table 1). In three plant species (Gomphrena globosa, Solanum americanum and Physalis pubescens) only TGVV was detected, and in Datura stramonium and Nicotiana tabacum cv. Samsun only ToSRV infection was confirmed (Table 1). All tomato plants were infected, confirming the efficiency of the inoculation method, and exhibited clear symptoms: vein clearing, mild leaf rolling and interveinal chlorosis in TGVV-infected plants, and rugosity, stunting, and strong interveinal chlorosis in ToSRV-infected plants. N. physaloides plants were also highly susceptible and showed chlorotic spots and mild leaf distortion when infected with either virus. $N$. physaloides plants play an important role as a ToSRV reservoir (Barbosa et al. 2009), and our results suggest that it may likely play such a role for TGVV as well. ToSRV and TGVV did not cause any visible symptoms in the other infected plants during the 3week evaluation period.

Other ToSRV isolates have been reported to be able to infect Euphorbia heterophylla (Barbosa et al. 2011; Barreto et al. 2013) and Phaseolus vulgaris (Barbosa et al. 2011), suggesting that its host range may be variable among isolates and inoculation conditions. In our study, the host range was evaluated in a free-choice test, and it is possible that some

Table 1 Infection rate after free-choice whitefly inoculation of Tomato severe rugose virus (ToSRV) and Tomato golden vein virus (TGVV) in plants of different species

\begin{tabular}{llllll}
\hline \multirow{2}{*}{ Host species } & \multicolumn{2}{l}{ ToSRV } & & & \multicolumn{2}{l}{ TGVV } \\
\cline { 2 - 3 } \cline { 6 - 7 } & $\mathrm{I}^{\mathrm{a}} \mathrm{T}^{\mathrm{a}}$ & $(\%)$ & & $\mathrm{I} / \mathrm{T}^{\mathrm{a}}$ & $(\%)$ \\
\hline Capsicum baccatum cv. Mari & $1 / 8$ & 12.5 & & $2 / 11$ & 18.2 \\
Datura stramonium & $1 / 10$ & 10.0 & & $0 / 10$ & 0.0 \\
Gomphrena globosa & $0 / 5$ & 0.0 & & $3 / 5$ & 60.0 \\
Physalis pubescens & $0 / 10$ & 0.0 & & $1 / 10$ & 10.0 \\
Nycandra physaloides & $10 / 10$ & 100.0 & & $10 / 10$ & 100.0 \\
Nicotiana rustica & $2 / 10$ & 20.0 & & $1 / 10$ & 10.0 \\
N. tabacum cv. Samsun & $1 / 10$ & 10.0 & & $0 / 10$ & 0.0 \\
Solanum americanum & $0 / 10$ & 0.0 & & $1 / 10$ & 10.0 \\
S. lycopersicum cv. Viradoro & $36 / 36$ & 100.0 & & $36 / 36$ & 100.0
\end{tabular}

${ }^{\mathrm{a}} \mathrm{I} / \mathrm{T}=$ number of infected plants (detected by PCR)/total number of inoculated plants 
plant species may not have been preferentially inoculated by the whitefly vectors in the presence of a more attractive host in the same cage. Both viruses, however, were tested in identical trials, hence our results are useful for a comparison of the host ranges of the two viruses.

$S$. americanum is a common weed in tomato fields throughout Brazil, whereas G. globosa and P. pubescens are not commonly found in the field. The ability of TGVV to infect S. americanum may confer an advantage to its survival and spread in the field, as reported for the displacement of Tomato yellow leaf curl Sardinia virus by Tomato yellow leaf curl virus (TYLCV-Is) due to the latter's ability to infect $P$. vulgaris plants (Sánchez-Campos et al. 1999). The TGVV isolate, however, clearly did not benefit by being able to infect $S$. americanum plants. The low infection rate observed in this trial may contribute to the reduced importance of $S$. americanum for the maintenance and spread of TGVV isolates in the field. ToSRV, however, could infect $N$. tabacum and D. stramonium. Tobacco plants are normally not found in tomato fields, but D. stramonium plants are common weeds in northeastern Brazil although less common in the south-central region. These observations imply that the differences in host range determined using the free-choice test may not be the determinant factor for the predominance of ToSRV in the field.

The transmission efficiency was next tested for each virus. Three viruliferous insects were confined in plastic cups containing single tomato plants at the 3-4 true-leaf stage. After inoculation, the cups were carefully removed, and the whiteflies were killed by subsequent treatment with thiamethoxam. The plants were then grown in an insect-proof greenhouse for 3 weeks for symptom evaluation and infection analysis. Pairwise comparisons of transmission efficiency were performed using Fisher's exact test at $P<0.05$ [R version 2.5.1 (06.27.2007), The R Foundation for Statistical Computing].

After the inoculation access period, only plants with at least one living insect were considered for the analyses. Two trials were performed. Obvious symptoms of infection (interveinal chlorosis, leaf curling, and stunting) were observed in plants infected with ToSRV at 3 weeks post-inoculation. Plants inoculated with TGVV initially exhibited strong vein-clearing but later became nearly asymptomatic.

The rate of transmission in both trials was higher for ToSRV than TGVV (Table 2). The proportion of plants infected by ToSRV was higher in all tests in both single and mixed infections. The average percentage of infection was approximately five times higher in plants inoculated with ToSRV $(41.86 \%)$ than in plants inoculated with TGVV $(8.33 \%)$ (Table 2). This difference was more evident in mixed infections. The average percentage of plants infected with only ToSRV was $38.37 \%$ and with only TGVV was $0.02 \%$. Only three of 81 plants were infected with both viruses. These results indicated that this ToSRV isolate was more efficiently transmitted by whiteflies than the TGVV isolate.
Table 2 Percentage of tomato plants infected by Tomato severe rugose virus (ToSRV) and Tomato golden vein virus (TGVV) in single and mixed whitefly mediated inoculations, as detected by PCR

\begin{tabular}{lllll}
\hline Inoculated virus & Detected virus & Trial 1 & Trial 2 & Average (\%) \\
\hline ToSRV & ToSRV $^{\mathrm{a}}$ & $8 / 27^{\mathrm{f}}$ & $10 / 16^{\mathrm{f}}$ & $41.86 \mathrm{a}^{\#}$ \\
TGVV & TGVV $^{\mathrm{b}}$ & $2 / 22$ & $1 / 14$ & $8.33 \mathrm{~b}$ \\
ToSRV + TGVV & ToSRV $^{\mathrm{c}}$ & $13 / 30$ & $18 / 51$ & $38.37 \mathrm{~A}$ \\
& TGVV $^{\mathrm{d}}$ & $1 / 30$ & $1 / 51$ & $0.02 \mathrm{~B}$ \\
& ToSRV $^{\text {TGVV }}$ & $1 / 30$ & $2 / 51$ & $0.04 \mathrm{~B}$ \\
\hline
\end{tabular}

${ }^{\#}$ Different lowercase and uppercase letters indicate significant differences in single and mixed infections, respectively, at $P<0.05$ (Fisher's exact test)

${ }^{\text {a }}$ Plants inoculated with ToSRV in single infection

${ }^{\mathrm{b}}$ Plants inoculated with TGVV in single infection

${ }^{\mathrm{c}}$ Plants inoculated with both viruses and positive only for ToSRV

${ }^{\mathrm{d}}$ Plants inoculated with both viruses and positive only for TGVV

${ }^{\mathrm{e}}$ Plants inoculated with and positive for both viruses

${ }^{\mathrm{f}}$ Number of infected plants/number of inoculated plants

To test if the inoculation efficiency was due to a differential acquisition rate of each virus by the insects, we collected whiteflies after the acquisition period ( $48 \mathrm{~h}$ ) on infected tomato plants and tested them in two trials by PCR for the presence of the two begomoviruses. The extraction of total DNA and the PCRs were performed as described earlier. Individual insects fed on ToSRV-, TGVV-, or doubly-infected plants were tested (Table 3). The average rate of infected whiteflies fed on single-infected plants was $85 \%$ for both viruses. PCR is a

Table 3 Acquisition efficiency of Tomato severe rugose virus (ToSRV) and Tomato golden vein virus (TGVV) by insects when fed on tomato leaves with single and mixed infections

\begin{tabular}{lllll}
\hline \multirow{2}{*}{ Viral source } & \multirow{2}{*}{ Detected } & \multicolumn{2}{l}{ Number of viruliferous insects } \\
\cline { 3 - 5 } & & Trial 1 & Trial 2 & Average (\%) \\
\hline ToSRV & ToSRV $^{\mathrm{a}}$ & $8 / 10^{\mathrm{f}}$ & $9 / 10^{\mathrm{f}}$ & 85 \\
TGVV & TGVV $^{\mathrm{b}}$ & $8 / 10$ & $9 / 10$ & 85 \\
ToSRV + TGVV & ToSRV $^{\mathrm{c}}$ & $0 / 10$ & $0 / 10$ & 0 \\
& TGVV $^{\mathrm{d}}$ & $0 / 10$ & $0 / 10$ & 0 \\
& ToSRV + TGVV $^{\mathrm{e}}$ & $10 / 10$ & $10 / 10$ & 100 \\
\hline
\end{tabular}

${ }^{\text {a }}$ Insects fed on ToSRV-infected leaves and viruliferous (PCR) for ToSRV

${ }^{\mathrm{b}}$ Insects fed on TGVV-infected leaves and viruliferous (PCR) for TGVV

${ }^{\mathrm{c}}$ Insects fed on ToSRV- and TGVV-infected leaves and viruliferous (PCR) only for ToSRV

${ }^{\mathrm{d}}$ Insects fed on ToSRV- and TGVV-infected leaves and viruliferous (PCR) only for TGVV

${ }^{\mathrm{e}}$ Insects fed on ToSRV- and TGVV-infected leaves and viruliferous (PCR) for ToSRV and TGVV

${ }^{\mathrm{f}}$ Number of viruliferous insects (PCR)/total number of insects 
highly sensitive technique, so these results suggest that some whiteflies may not have fed under the presumably stressful situation of the acquisition procedure. Both viruses were detected in all individual insects confined with leaves infected with both viruses, indicating that the acquisition rate of ToSRV and TGVV did not differ substantially under the test conditions.

Begomoviruses have been reported to infect tomato plants in Brazil since the 1960's. Tomato golden mosaic virus was the first species reported in tomato plants (Costa 1976). Many new species and isolates have since been reported in most tomato-growing regions of the country, coinciding with the increase and spread of $B$. tabaci populations (Ambrozevicius et al. 2002; Ribeiro et al. 2003; Fernandes et al. 2006, 2008; Albuquerque et al. 2010). The predominance of ToSRV in Brazilian tomato fields was reported in samples collected from 1994 to 2004 (Fernandes et al. 2008) and in those collected recently (data not shown). In our tests, the ToSRV isolate was transmitted by whiteflies significantly more efficiently than TGVV. This difference was most likely related to the inoculation efficiency, because both viruses were acquired at a similar rate. The monopartite begomoviruses Tomato yellow leaf curl Sardinia virus and Tomato yellow leaf curl virus were acquired at similar levels by $B$. tabaci biotypes $\mathrm{B}$ and Q but were transmitted to tomato plants at different rates (SánchezCampos et al. 1999).

We assessed the ability of the insects to acquire the two viruses by PCR-based detection of viral DNA. This test only indicated that the insects contained genomic DNA and not that they contained viruses able to infect healthy plants (McGrath and Harrison 1995). Strategies to detect viral particles in the salivary glands would better address this issue and will be tested in future studies. Wei et al. (2014) recently demonstrated that the B biotype of B. tabaci was able to efficiently transmit isolates of TYLCV-Is and of Tomato yellow leaf curl China virus (TYLCCNV), whereas the Q biotype could only transmit TYLCV-Is. These authors suggested that a barrier may be present to prevent the translocation of TYLCCNV particles to the primary salivary gland of the vector. Furthermore, exchanging part of the coat-protein gene between TYLCV-Is and TYLCCNV demonstrated the importance of the coat protein in transmission.

Many factors likely contribute to the population dynamics of viruses in the field, but our results indicate that the higher transmission efficiency of ToSRV by B. tabaci in tomato plants could be a major factor leading to the predominance of this species in the field. Other factors, such as host susceptibility, differences in whitefly populations and climatic adaptation may also affect the fitness of a species and will be examined in future studies. Efforts to elucidate the factors contributing to the emergence and prevalence of begomoviral species are important to understand viral epidemiology and to assist in the development of effective management strategies.
Acknowledgments The authors are grateful to Lucio Flavio Barbosa, Hamilton José Lourenço, Oneilson Medeiros de Aquino and Pedro Paulo Ferreira Lemos for technical support. This research was financially supported by Embrapa, CNPq and CAPES. AKIN is a CNPq fellow.

\section{References}

Albuquerque LC, Martin DP, Ávila AC, Inoue-Nagata AK (2010) Characterization of Tomato yellow vein streak virus, a begomovirus from Brazil. Virus Genes 40:140-147

Ambrozevicius LP, Calegario RF, Fontes PB, Carvalho MG, Zerbini FM (2002) Diversidade genética de begomovírus infetando o tomateiro e plantas daninhas no Sudeste do Brasil. Fitopatol Bras 27:372-377

Barbosa JC, Barreto SS, Inoue-Nagata AK, Reis MS, Firmino AC (2009) Natural infection of Nicandra physaloides by Tomato severe rugose virus in Brazil. J Gen Plant Pathol 75:440-443

Barbosa JC, Barreto AA, Inoue-Nagata AK, Rezende JAM (2011) Caracterization and experimental host range of a Brazilian tomato isolate of Tomato severe rugose virus. J Phytopathol 159:644-646

Barreto SS, Hallwass M, Aquino OM, Inoue-Nagata AK (2013) A study of weeds as potential inoculum sources for a tomato-infecting begomovirus in central Brazil. Phytopathology 103:436-444

Bosco D, Loria A, Sartor C, Cenis JL (2006) PCR-RFLP identification of Bemisia tabaci biotypes in the Mediterranean Basin. Phytoparasitica 34:243-251

Brown JK, Fauquet CM, Briddon RW, Zerbini FM, Moriones E, NavasCastillo J (2012) Geminiviridae. In: King AMQ, Adams MJ, Carstens EB, Lefkowitz EJ (eds) Virus taxonomy. Ninth Report of the International Committee on Taxonomy of Viruses. Elsevier Academic Press, San Diego

Calegario RF, Ferreira SS, Andrade EC, Zerbini FM (2007) Characterization of Tomato yellow spot virus (ToYSV), a novel begomovirus infecting tomatoes in Brazil. Pesq Agrop Brasileira 42:1335-1342

Castillo-Urquiza GP, Beserra-Junior JEA, Bruckner FP, Lima ATM, Varsani A, Alfenas-Zerbini P, Zerbini FM (2008) Six novel begomoviruses infecting tomato and associated weeds in Southeastern Brazil. Arch Virol 153:1985-1989

Costa AS (1976) Whitefly-transmitted plant diseases. Annu Rev Phytopathol 16:429-449

Doyle JJ, Doyle JL (1987) A rapid DNA isolation procedure for small quantities of fresh leaf tissue. Phytochem Bull 19:11-15

Faria JC, Bezerra IC, Zerbini FM, Ribeiro SG, Lima MF (2000) Situação atual das geminiviroses no Brasil. Fitopatol Bras 25:125-137

Fernandes JJ, Carvalho MG, Andrade EC, Brommoschenkel SH, Fontes EPB, Zerbini FM (2006) Biological and molecular properties of Tomato rugose mosaic virus (ToRMV), a new tomato-infecting begomovirus from Brazil. Plant Pathol 55:513-522

Fernandes FR, Albuquerque LC, Giordano LB, Boiteux LC, Ávila AC, Inoue-Nagata AK (2008) Diversity and prevalence of Brazilian bipartite begomovirus species associated to tomatoes. Virus Genes 36 : 251-258

Fernandes FR, Albuquerque LC, Inoue-Nagata AK (2010) Development of a species-specific detection method for three Brazilian tomato begomoviruses. Trop Plant Pathol 35:43-47

Frohlich DR, Torres-Jerez I, Bedford ID, Markham PG, Brown JK (1999) A phylogeographical analysis of the Bemisia tabaci species complex based on mitochondrial DNA markers. Mol Ecol 8:1683-1691

Ghanim M, Morin S, Czosnek H (2001) Rate of Tomato yellow leaf curl virus translocation in the circulative transmission pathway of its vector, the whitefly Bemisia tabaci. Phytopathology 91:188-196 
Hunter WB, Hiebert E, Webb SE, Tsai JH, Polston JE (1998) Location of geminiviruses in the whitefly Bemisia tabaci (Homoptera: Aleyroididae). Plant Dis 82:1147-1151

McGrath PF, Harrison BD (1995) Transmission of tomato leaf curl geminiviruses by Bemisia tabaci: effect of virus isolate and vector biotype. Ann Appl Biol 126:307-316

Morales FJ, Anderson PK (2001) The emergence and dissemination of whitefly-transmitted geminiviruses in Latin America. Arch Virol 146:415-441

Ribeiro SG, Ambrozevicius LF, Ávila AC, Bezerra IC, Calegario RF, Fernandes JJ, Lima MF, Mello RN, Rocha H, Zerbini FM (2003) Distribution and genetic diversity of tomato-infecting begomovius in Brasil. Arch Virol 148:281-295

Rocha CS, Castillo-Urquiza GP, Lima ATM, Silva FN, Xavier CAD, Hora-Junior BT, Beserra-Junior JEA, Malta AWO, Martin DP, Varsani A, Alfenas-Zerbini P, Mizubuti ESG, Zerbini FM (2013) Brazilian begomovirus populations are highly recombinant, rapidly evolving, and segregated based on geographical location. J Virol 87: 5784-5799
Rojas MR, Hanges C, Lucas WJ, Gilbertson RL (2005) Exploiting chinks in the plant's armor: evolution and emergence of geminiviruses. Annu Rev Phytopathol 43:361-394

Rosello S, Soler M, Diez MJ, Rambla JR, Richarte C (1999) New sources for high resistance of tomato to Tomato spotted wilt virus from Lycopersicon peruvianum. Plant Breed 118:425429

Sánchez-Campos S, Navas-Castillo J, Camero R, Soria C, Díaz JA, Moriones E (1999) Displacement of tomato yellow leaf curl virus (TYLCV)-Sr by TYLCV-Is in tomato epidemics in Spain. Phytopathology 89:1038-1043

Simon C, Frati F, Beckenbach A, Crespi B, Liu H, Flook P (1994) Evolution, weighting, and phylogenetic utility of mitochondrial gene sequences and a compliation of conserved polymerase chain reaction primers. Ann Entomol Soc Am 87:651-701

Wei J, Zhao JJ, Zhang T, Li FF, Ghanim M, Zhou XP, Ye GY, Liu SS, Wanga XW (2014) Specific cells in the primary salivary glands of the whitefly Bemisia tabaci control retention and transmission of begomoviruses. J Virol 88:13460-13468 